\title{
Pengaruh Penerapan Media Benda Asli Pada Mata Pelajaran Matematika Terhadap Hasil Belajar Siswa Kelas III Di MI/SD
}

\author{
Idzi’ Layyinati \\ Sekolah Tinggi Ilmu Tarbiyah Muhammadiyah Paciran, Indonesia \\ Email:idziela@gmail.com
}

\begin{abstract}
Abstrak: Pada suatu lembaga pendidikan yang bersifat formal seperti Madrasah, keberhasilan pendidikan dapat dilihat dari hasil belajar siswa dalam prestasi belajarnya. Kualitas dan keberhasilan belajar siswa sangat dipengaruhi oleh kemampuan dan ketepatan guru memilih dan menggunakan metode maupun media yang bervariasi dalam meningkatkan keefektifan siswa dalam belajar. Judul penelitian ini adalah "Pengaruh Penerapan Media Benda Asli Pada Mata Pelajaran Matematika Terhadap Hasil Belajar Siswa Kelas III di Madrasah Ibtida'iyah. Penelitian yang digunakan yakni eksperimen dengan pendekatan kuantitatif. Adapun pengambilan sampel dalam penelitian ini, penulis hanya mengambil kelas III sebagai kelas eksperimen yang berjumlah 27 siswa berdasarkan random sampling dan hasil observasi penulis terhadap siswa kelas III mengenai rendahnya hasil belajar siswa terhadap mata pelajaran Matematika. Teknik pengumpulan data penelitian ini menggunakan observasi, tes (pre-test dan post-test). Analisis data untuk mengambil kesimpulan menggunakan rumus tes " $t$ " untuk sampel kecil yang saling berhubungan. Hasil penelitian ini yaitu hasil observasi menunjukkan bahwa penerapan media benda asli pada mata pelajaran Matematika tergolong baik. Hasil belajar siswa pada pos-test mengalami peningkatan skor mean jika dibandingkan dengan pre-test. Sedangkan untuk uji perbandingan didapatkan kesimpulan setelah membandingkan besarnya $t_{\text {tabael }} 1 \%$ dan 5\% adalah 2,78 dan 2,06 yang diperoleh dalam perhitungan $\left(t_{o}\right)$ adalah 16,23. Sehingga pada penilitian menyimpulkan bahwa ada pengaruh penerapan media benda asli terhadap hasil belajar siswa kelas III di MI/SD.
\end{abstract}

Kata Kunci: Pengaruh, penerapan, media benda asli, matematika, hasil belajar siswa. 


\begin{abstract}
In a formal educational such as a Madrasah, the success of education can be seen from the student learning outcomes in learning achievement. The quality and success of the students learning is strongly influenced by the ability and accuracy of the teachers choosing, using methods and media that is can be improve the effectiveness of the students learning process. The title of this research is "The Effect of the Application of Original Material Media on Mathematics Subjects to the Learning Outcomes of Thirth Grade Students in elementary school. The research used is an experiment with a quantitative approach. As for the sampling in this study, the authors only take Thirth Grade as an experimental class totaling 27 students based on random sampling and the results of the observation of the author towards third grade students regarding the low student learning outcomes on Mathematics subjects. The data collection technique of this study uses observation, tests (pre-test and post-test). Data analysis to draw conclusions using the " $t$ " test formula for small, interconnected samples.. As for the results of this study, the results of the observations showed that the application of the original object media in Mathematics subjects was good. Student learning outcomes in the post-test have increased mean scores when compared with the pre-test. Whereas for the comparison test obtained a conclusion after comparing the amount of $t_{\text {tabael }} 1 \%$ dan $5 \%$ is 2,78 dan 2,06 obtained in the calculation $t_{o}$ is 16,23. So that the research concludes that there is an effect of the application of the original object media to the learning outcomes of Thirth Grade students in elementary school.
\end{abstract}

Keywords: Influence, application, media of original objects, mathematics, student learning

outcomes. 
Pendidikan adalah usaha sadar dan terencana untuk mewujudkan suasana belajar dan proses pembelajaran agar peserta didik secara aktif mengembangkan potensi dirinya untuk memiliki kekuatan keagamaan, pengendalian diri, kepribadian, kecerdasan, akhlak mulia, serta keterampilan yang diperlukan dirinya, masyarakat, bangsa dan negara. ${ }^{1}$ Matematika adalah ilmu dari segala ilmu, artinya banyak disiplin ilmu yang dalam kajiannya membutuhkan matematika. Ilmu ini memiliki peranan yang sangat penting dalam kehidupan sehari-hari. Berbagai bentuk simbol, rumus, dalil, ketetapan, maupun konsep digunakan untuk membantu perhitungan, pengukuran, penilaian dan penaksiran.Matematika juga merupakan salah satu bidang studi yang ada pada semua jenjang pendidikan, mulai dari tingkat sekolah dasar hingga perguruan tinggi. Bahkan matematika diajarkan di taman kanak-kanak secara informal. Belajar matematika merupakan suatu syarat cukup melanjutkan pendidikan kejenjang berikutnya. Karena dengan belajar matematika, kita akan belajar bernalar secara kritis, kreatif, dan aktif. Matematika merupakan ide-ide abstrak yang berisi simbol-simbol.

Dalam proses pembelajaran, guru yang mengajar dan murid yang diajar dan yang diajarkan adalah mata pelajaran atau satuan pendidikan tertentu. Mata pelajaran tersebut salah satunya adalah Matematika. Matematika merupakan satuan pendidikan yang membimbing dan melatih murid belajar untuk berhitung, menambah, mengurangi, membagi, dan mengalikan. Proses berhitung tersebut disebut Matematika.Guru dalam hal mengajar, harus memiliki keahlian sebagai guru. Salah satunya adalah mampu memberikan motivasi atau minat, meningkatkan keinginan anak didik dalam belajar di sekolah. Karena itu guru harus memiliki benar tentang tujuan mengajar, secara khusus memilih dan menentukan metode mengajar sesuai dengan tujuan yang hendak dicapai, memahami bahan pelajaran sebaik mungkin dengan menggunakan sumber, cara memilih, menentukan, dan menggunakan media, cara membuat tes, cara membuat huruf atau tulisan, dan cara membaca yang baik dan benar serta berpengetahuan dan memiliki pengatahuan tentang alat-alat evaluasi pengajaran. ${ }^{3}$

Peradaban manusia berubah dengan pesat karena ditunjang oleh adanya peran serta matematika yang selalu mengikuti perkembangan ilmu pengetahuan teknologi. Pengetahuan dan keterampilan matematika merupakan salah satu hal yang harus dimiliki siswa agar mampu berpikir, bersikap, dan berbuat demi mencapai keberhasilan hidup seharihari di masyaraka Pada umumnya matematika merupakan salah satu mata pelajaran yang kurang diminati siswa, karena kebanyakan dari materi matematika bersifat abstrak. Tujuan pembelajaran matematika di sekolah adalah untuk mengembangkan sikap, pola fikir logis, rasional, kritis, cermat, jujur, efektif, dan efisien, serta bisa menerapkan dalam kehidupan sehari-hari.Tercapainya tujuan diatas merupakan tolak ukur keberhasilan dalam proses pembelajaran. Kenyataan di lapangan 
mutu pendidikan matematika diduga telah tergolong memprihatinkan yang ditandai dengan rendahnya nilai ratarata matematika siswa di sekolah lebih rendah jika dibandingkan dengan nilai mata pelajaran lainnya. Hal ini disebabkan penguasaan konsep dasar matematika masih kurang antara lain dalam memahami rumus, dan konteks kehidupan yang nyata dengan ilmu matematika.

Dalam suatu proses belajar mengajar, dua unsur yang sangat penting adalah metode mengajar dan media pembelajaran. Kedua aspek ini saling berkaitan. Pemilihan salah satu metode mengajar tertentu akan mempengaruhi jenis media pembelajaran yang sesuai, meskipun masih ada berbagai aspek yang harus diperhatikan dalam memilih media pembelajaran antara lain tujuan pembelajaran, dan karakteristik siswa. Adapun fungsi utama media pembelajaran adalah sebagai alat bantu mengajar guru. Salah satu taktik untuk meningkatkan hasil belajar siswa adalah dengan menggunakan media pembelajaran yang dapat membuat siswa-siswi mengerti dengan materi yang disampaikan. Salah satu media yang dapat digunakan untuk proses belajar mengajar Matematika adalah media benda asli.

Media benda asli merupakan benda yang sebenarnya membantu pengalaman nyata peserta didik dan menarik minat dan semangat belajar siswa. Dengan menggunakan media benda asli akan memberikan rangsangan yang amat penting bagi siswa untuk mempelajari berbagai hal terutama menyangkut pengembangan keterampilan. Penelitian di Madrasah Ibtidaiyah
Muhammadiyah 06 Tebluru ini dilatar belakangi oleh pelajaran Matematika merupakan pelajaran pokok dan dianggap sulit sehingga diperlukan pemahaman yang cukup untuk melakukan pengajaran yang telah diberikan apalagi untuk anak kelas III MI Jadi untuk mengaktifkan siswa-siswi dalam proses pembelajaran Matematika dibutuhkan alat bantu atau media untuk mengaktifkan dan membuat siswa menjadi lebih paham atas materi yang disampaikan oleh gurunya. Hal lain yang melatar belakangi penelitian di Madrasah Ibtidaiyah Muhammadiyah 06 Tebluru ini adalah hasil observasi penulis terhadap siswa kelas III mengenai rendahnya hasil belajar siswa terhadap mata pelajaran Matematika.

Berdasarkan latar belakang yang telah penulis paparkan di atas, penulis tertarik untuk melakukan penelitian yang mendalam mengenai "Pengaruh Penerapan Media Benda Asli Mata Pelajaran Matematika terhadap Hasil Belajar Siswa Kelas III di MI/SD.

\section{Metode}

Data yang diperlukan sebagaimana tersebut di atas diperoleh dengan metode:

1. Metode Observasi

Secara umum, Observasi adalah cara menghimpun bahan-bahan keterangan (data) yang dilakukan dengan mengadakan pengamatan dan pencatatan secara sistematis terhadap fenomena-fenomena yang sedang dijadikan sasaran pengamatan. $^{23}$ Metode ini dipergunakan untuk 
mengadakan pengamatan secara langsung ke tempat lokasi penelitian, keadaan wilayah, letak geografis, keadaan sarana dan prasarana serta kondisi pada saat proses pelaksanaan pembelajaran di Madrasah Ibtidaiyah Muhammadiyah 06 Tebluru Kecamatan Solokuro Kabupaten Lamongan pada Tahun Pelajaran 2017 - 2018 Tahun Pelajaran 2017 - 2018.

2. Metode Tes

Metode tes digunakan untuk mengukur kemampuan individu siswa. Serta peningkatan nilai siswa sebelum dan sesudah mendapat perlakuan, pada kelas eksperimen. Jenis test yang diberikan kepada siswa berupa pilihan ganda sebanyak 10 soal.

Langkah-langkahnya sebagai berikut:

a) Mengadakan Pre-Test

Tes yang diberikan kepada siswa sebelum mereka mengikuti program pembelajaran. Soal-soal dalam pre-test berfaedah sebagai bahan perbandingan dengan hasil post-test setelah siswa mengikuti program pembelajaran

b) Mengadakan Post-Test (Evaluasi)

Jika pre-test diberikan sebelum mengikuti proses pembelajaran, maka posttest diberikan setelah siswa mengikuti proses pembelajaran dan yang diberikan pada post-test adalah soal yang sama dengan soal yang diberikan pada pre-test..

Analisa pada penelitian ini menggunakan rumus statistik tes " $\mathrm{t}$ " ( $\mathrm{t}$ hitung) untuk dua sampel kecil ( $\mathrm{N}$ kurang dari 30), sedangkan ke dua sampel kecil itu satu sama lain mempunyai pertalian atau hubungan. Adapun rumus yang digunakan yaitu: ${ }^{24}$

a. Mencari D (Difference $=$ Perbedaan) antara skor Variabel I dan skor variabel II. Jika variabel I (variabel X) dan skor Variabel II (variabel $\mathrm{Y})$, maka $\mathrm{D}=$ $\mathrm{X}-\mathrm{Y}$

b. Menjumlahkan D, sehingga diperoleh $\sum \mathrm{D}$

c. Mencari Mean dari Difference dengan rumus $\mathrm{M}_{\mathrm{D}}=$ Mean of Difference $=$ Nilai ratarata Hitung dari beda atau selisih antara skor Variabel I dan Variabel II

$M_{D}==\frac{\text { Mean of Difference }}{M_{D}} \frac{\sum \mathrm{D}}{N}$

d. Menguadratkan D, setelah itu lalu dijumlahkan sehingga diperoleh $\sum \mathrm{D}^{2}$

e. Mencari Deviasi standar dari Difference $S D_{D} \quad$ yang dapat diperoleh dengan rumus: 
Idzi’ Layyinati

$S D D=\sqrt{\frac{\sum \mathrm{D}^{2}}{N}-\left(\frac{\sum \mathrm{D}}{N}\right)^{2}}$

$N=$ Number Of Case $=$ Jumlah Subjek yang kita teliti

f. Mencari Standard Error dari Mean of Diffencce yaitu

$\mathrm{SE}_{\mathrm{MD}}=$ Standard error (Standar Kesesatan) dan mencari Mean of Differnce yang dapat diperoleh dengan rumus:

$S E M D D=\frac{S D D}{\sqrt{N-1}}$

g. Mencari $t_{0}$ (t tabel) dengan rumus:

$\mathrm{t}_{\mathrm{o}}=\frac{M D}{S E \mathrm{M}_{\mathrm{D}}}$ h. Memberikan interpretasi terhadap" $\mathrm{t}_{\mathrm{o}}$ " ( $\mathrm{t}$ tabel)

i. Menarik kesimpulan hasil penelitian.

1) $D f \quad$ (Degress of Freedom) atau $d f$ $($ Derajat Bebas $)=(\mathrm{N}-$ 1)

2) Berkonsultasi pada tabel nilai "t" taraf signifikan 5 $\%$

\section{Hasil Dan Pembahasan}

Dari analisis lembar observasi keaktifan siswa terdiri dari 3 indikator yang diamati oleh peneliti. Yang indikatornya yaitu:

a. Siswa memperhatikan penjelasan materi dari guru.

b. Siswa bersemangat mengerjakan soal.

c. Siswa tidak mengalami kesulitan dalam mengerjakan soal.

Untuk lebih jelas mengenai kegiatan indikator hasil observasi yang dilakukan siswa, dapat dilihat dalam tabel dibawah ini:

Tabel. 5

Analisis Lembar Aktivitas Siswa

\begin{tabular}{|l|l|l|l|l|l|l|l|l|l|}
\hline \multirow{2}{*}{ No } & \multirow{2}{*}{ Nama Siswa } & \multicolumn{6}{|c|}{ Deskripsi Kegiatan Aktifitas } & \multirow{2}{*}{ Skor } & \multirow{2}{*}{ Kategori } \\
\cline { 3 - 7 } & & $\mathbf{1}$ & $\mathbf{2}$ & $\mathbf{3}$ & $\mathbf{4}$ & $\mathbf{5}$ & $\mathbf{6}$ & & \\
\hline 1 & Ain Dwi K. & 4 & 4 & 3 & 3 & 3 & 4 & 21 & Baik \\
\hline 2 & Aisyatul Dayana & 2 & 4 & 4 & 4 & 3 & 3 & 20 & Baik \\
\hline 3 & Akbar Aditya R. & 4 & 4 & 4 & 4 & 3 & 3 & 22 & Baik \\
\hline 4 & Amilatus Sholihah & 2 & 3 & 2 & 4 & 3 & 4 & 18 & $\begin{array}{l}\text { Cukup } \\
\text { Baik }\end{array}$ \\
\hline 5 & Amiluddin. & 4 & 4 & 3 & 3 & 2 & 3 & 19 & $\begin{array}{l}\text { Cukup } \\
\text { Baik }\end{array}$ \\
\hline
\end{tabular}


Pengaruh Penerapan Media Benda Asli Pada Mata Pelajaran Matematika

\begin{tabular}{|l|l|l|l|l|l|l|l|l|l|}
\hline 6 & Anastasyahilah & 2 & - & - & 4 & 3 & 3 & 12 & $\begin{array}{l}\text { Kurang } \\
\text { Baik }\end{array}$ \\
\hline 7 & Batrisyia Elkasih & 3 & 3 & 4 & 4 & 3 & 4 & 21 & Baik \\
\hline 8 & Batrisyia Wanda & 4 & 4 & 2 & - & 4 & 3 & 17 & $\begin{array}{c}\text { Cukup } \\
\text { Baik }\end{array}$ \\
\hline 9 & Berrin Widiyanata & 3 & 3 & 4 & 4 & 4 & 3 & 21 & Baik \\
\hline 10 & Dannel Faruqi A. & 2 & 4 & 3 & 3 & 4 & 3 & 19 & $\begin{array}{c}\text { Cukup } \\
\text { Baik }\end{array}$ \\
\hline 11 & Dhamar Althof F. & 4 & 3 & 4 & 4 & 2 & 4 & 21 & Baik \\
\hline 12 & Eka Setiyawati & 4 & 3 & 4 & 4 & 4 & 3 & 22 & Baik \\
\hline 13 & Fikri Haikal & 2 & 4 & 3 & 3 & 4 & 3 & 19 & $\begin{array}{l}\text { Cukup } \\
\text { Baik }\end{array}$ \\
\hline 14 & Firas Aqil & 4 & 4 & 4 & 3 & 4 & 4 & 23 & Baik \\
\hline 15 & Hafizah Khaira & 4 & 4 & 4 & 4 & 4 & 4 & 24 & Baik \\
\hline 16 & I'laniyah A. & 4 & 3 & 4 & 2 & 3 & 4 & 20 & Baik \\
\hline 17 & Kayla Putri M. & 3 & 3 & 4 & 2 & 3 & 2 & 17 & $\begin{array}{l}\text { Cukup } \\
\text { Baik }\end{array}$ \\
\hline 18 & Kelvin Aditya & 4 & 4 & 4 & 4 & 4 & 4 & 24 & Baik \\
\hline
\end{tabular}

\begin{tabular}{|l|l|l|l|l|l|l|l|l|l|}
\hline \multirow{2}{*}{ No } & \multirow{2}{*}{ Nama Siswa } & \multicolumn{6}{|c|}{ Deskripsi Kegiatan Aktifitas } & \multirow{2}{*}{ Skor } & Kategori \\
\cline { 3 - 12 } & & $\mathbf{1}$ & $\mathbf{2}$ & $\mathbf{3}$ & $\mathbf{4}$ & $\mathbf{5}$ & $\mathbf{6}$ & & \\
\hline 19 & M. Athok A. & 3 & 3 & 3 & 4 & 3 & 4 & 20 & Baik \\
\hline 20 & Miftakhul Jannah & 3 & - & 4 & 3 & 4 & 2 & 16 & Cukup Baik \\
\hline 21 & $\begin{array}{l}\text { M. Nawaf Al } \\
\text { Mubarok }\end{array}$ & & & 3 & 4 & 3 & 4 & 22 & Baik \\
\hline 22 & M. Reyhan F. & 3 & 4 & 3 & 4 & 3 & 3 & 20 & Baik \\
\hline 23 & Ratna Angelina & 3 & 2 & - & 4 & 3 & 4 & 16 & Cukup Baik \\
\hline 24 & Rizky Andesta & 4 & 3 & 4 & 4 & 2 & 3 & 20 & Baik \\
\hline 25 & Yosi Afmi A. & 3 & 3 & 2 & 3 & 4 & 3 & 18 & Cukup Baik \\
\hline
\end{tabular}


Idzi’ Layyinati

\begin{tabular}{|l|l|l|l|l|l|l|l|l|l|}
\hline 26 & Zahira Aurotsana & 4 & 4 & 4 & 3 & 4 & 4 & 23 & Baik \\
\hline 27 & Zayed Ar Rahman & 4 & 4 & 4 & 4 & 4 & 4 & 24 & Baik \\
\hline
\end{tabular}

Keterangan:

Angka $1-6=$ Frekuensi pertemuan.

$4=$ jika semua descriptor muncul

$3=$ jika 2 deskriptor muncul

$2=$ jika 1 deskriptor muncul

$1 \quad=$ jika deskriptor tidak muncul

Kategori:

$\begin{array}{ll}\text { Baik } & =20-24 \\ \text { Cukup Baik } & =15-19 \\ \text { Kurang Baik } & =10-14\end{array}$

Tabel. 6

Rekapitulasi Observasi Aktivitas Siswa

\begin{tabular}{|l|l|l|l|}
\hline No & Kategori & Frekuensi & Persentase \\
\hline 1 & Baik & 17 orang & $63 \%$ \\
\hline 2 & Cukup Baik & 9 orang & $33 \%$ \\
\hline 3 & $\begin{array}{l}\text { Kurang } \\
\text { Baik }\end{array}$ & 1 orang & $4 \%$ \\
\hline \multicolumn{2}{|l}{ Jumlah } & $\mathbf{2 7}$ orang & $\mathbf{1 0 0 \%}$ \\
\hline
\end{tabular}

Berdasarkan tabel data rekapitulasi observasi siswa dapat diketahui bahwa ada 17 orang siswa (63\%) yang termasuk dalam kriteria baik yaitu siswa yang mengerjakan ketiga deskriptor kegiatan, 9 orang siswa $(33 \%)$ termasuk dalam kriteria cukup baik yaitu siswa yang hanya mengerjakan dua deskriptor kegiatan dan 1 orang siswa (4\%) yang termasuk dalam kriteria kurang baik yaitu siswa yang hanya mengerjakan satu deskriptor kegiatan. Dengan demikian penerapan media benda asli pada mata pelajaran Matematika siswa kelas III di Madrasah Ibtidaiyah Muhammadiyah $06 \quad$ Tebluru
Kecamatan Solokuro Kabupaten Lamongan Tahun Pelajaran 2017 2018 pada kriteria baik yakni 17 orang siswa $(63 \%)$ dari 27 siswa yang menjadi sampel penelitian ini.

1. Data Tes

Peneliti menggunakan metode tes untuk mendapatkan data yang diperlukan dalam penelitian ini. Data dalam penelitian ini adalah data yang diperoleh dari nilai siswa hasil eksperimen yang peneliti lakukan dalam pembelajaran Matematika.

Penerapan media benda asli pada mata pelajaran Matematika ini dilakukan 
sebanyak 6 kali pada kelas III sesuai dengan Rencana Pelaksanaan Pembelajaran (RPP) yang telah disusun oleh peneliti. Sebelum melaksanakan kegiatan proses pembelajaran, peneliti melakukan tes terlebih dahulu yaitu (pretest) sebelum tindakan serta peneliti melakukan tes setelah melaksanakan tindakan (post-test) di Madrasah Ibtidaiyah Muhammadiyah 06 Tebluru Kecamatan Solokuro Kabupaten Lamongan. Peneliti memberikan soal tes yang berbentuk pilihan ganda sebanyak 10 soal. Adapun butir-butir soal pre-test dan post-test disamakan. Untuk memberikan skor hasil jawaban pre-test dan post test siswa pada setiap butir soal pilihan ganda terlebih dahulu peneliti membuat Asli

\begin{tabular}{|c|c|c|c|c|c|c|c|}
\hline Interval & $f$ & $\mathrm{X}$ & $f \mathrm{X}$ & $\mathrm{X}^{\prime}$ & $\mathrm{X}^{2}$ & $f \mathrm{X}^{\prime}$ & $f \mathrm{X}^{2}$ \\
\hline $77-83$ & 1 & 80 & 80 & +3 & 9 & 3 & 9 \\
$70-76$ & 1 & 73 & 73 & +2 & 4 & 2 & 4 \\
$63-69$ & 5 & 66 & 330 & +1 & 1 & 5 & 5 \\
$56-62$ & 7 & 59 & 413 & 0 & 0 & 0 & 0 \\
$49-55$ & 8 & 52 & 416 & -1 & 1 & -8 & 8 \\
$42-48$ & 4 & 45 & 180 & -2 & 4 & -8 & 16 \\
$35-41$ & 1 & 38 & 38 & -3 & 9 & -3 & 9 \\
\hline Jumlah & $\mathrm{N}=\mathbf{2 7}$ & $\begin{array}{l}\mathrm{X} \\
=413\end{array}$ & $\begin{array}{l}f \mathrm{X} \\
=1530\end{array}$ & & $\begin{array}{l}f X^{u} \\
=-9\end{array}$ & $\begin{array}{c}f X^{\prime 2} \\
=51\end{array}$ \\
\hline
\end{tabular}

bobot penskoran atau acuan penskoran. Bobot skor dari seluruh soal jika benar semua maka mendapat skor 100. Jadi, skor tertinggi adalah 100 dan skor terendahnya adalah 0 dengan kriteria tidak benar jawaban yang diberikan. Adapun penelitian ini dilakukan pada kelas III berjumlah 27 siswa.

Dalam penelitian ini, hasil belajar sebelum diterapkannya media benda asli, diambil dari data hasil pre-test (sebelum) diterapakan media benda asli pada mata pelajaran Matematika, berikut lampiran hasil belajar siswa tersebut:

a. Hasil Pre-Test siswa yang dilakukan 6 kali pertemuan dapat dilihat sebagai berikut:

\section{Tabel. 6 \\ Distribusi Hasil Belajar Siswa Sebelum Diterapkan Media Benda}


Idzi’ Layyinati

$\begin{array}{rlrl}\text { Mencari } & & \text { mean data: } \\ \text { Mx } & =\frac{\sum f x}{N} \\ & =\frac{1530}{27} \\ & =57\end{array}$

Mencari Standar deviasi:

$$
\begin{aligned}
\mathrm{SDx} & =i \sqrt{\sum \frac{f x^{2}}{N}-\left(\frac{\sum f x}{N}\right)^{2}} \\
& =7 \sqrt{\frac{51}{27}-\left(\frac{-9}{27}\right)^{2}} \\
& =7 \sqrt{1,88-(-0,33)^{2}} \\
& =7 \sqrt{1,772} \\
& =7 \times 1,33 \\
& =9,31
\end{aligned}
$$

Tinggi $=\mathrm{My}+1 \mathrm{x}$ SDy

$=72,3+1 \times 8,82$

$=81,12$

= di bulatkan menjadi 81

Jadi, yang termasuk kategori nilai tinggi adalah 81 ke atas.

Sedang = My $-1 \mathrm{x}$ SDy s/d My $+1 \times$ SDy

$=72,33-1 \times 8,82 \mathrm{~s} / \mathrm{d} 72,33+1 \times 8,82$

$=63,51 \mathrm{~s} / \mathrm{d} 81,12$

$=$ di bulatkan menjadi $64 \mathrm{~s} / \mathrm{d} 81$

Jadi, kategori nilai sedang yaitu antara 64 s/d 81

Rendah $=$ My $-1 \times$ SDy

$=72,33-1 \times 8,82$

$=63,51$

= di bulatkan menjadi 64 Karena nilai 64 sudah termasuk ke dalam kategori nilai sedang.

Jadi, nilai 64 ke bawah termasuk kategori nilai rendah. 
Tabel. 7

Persentase Hasil Belajar Siswa Kelas III

\begin{tabular}{|c|c|c|c|c|}
\hline No & $\begin{array}{ll}\text { Hasil } & \text { Belajar } \\
\text { Matematika } & \end{array}$ & Nilai & Frekuensi & $\begin{array}{l}\text { Persentas } \\
\mathrm{e}\end{array}$ \\
\hline 1 & Tinggi & $81 \mathrm{ke}$ atas & 3 & $11,11 \%$ \\
\hline 2 & Sedang & $64 \mathrm{~s} / \mathrm{d} 81$ & 20 & $74,07 \%$ \\
\hline 3 & Rendah & $\begin{array}{ll}64 & \text { ke } \\
\text { bawah } & \end{array}$ & 4 & $14,82 \%$ \\
\hline & \multicolumn{2}{|l|}{ Jumlah } & $\mathrm{N}=27$ & $100 \%$ \\
\hline
\end{tabular}

Setelah diurutkan, data distribusikan ke dalam tabel distribusi sebagai berikut:

Tabel. 8

Distribusi Hasil Belajar Siswa Sesudah Diterapkan Media Benda Asli

\begin{tabular}{|c|c|c|c|c|c|c|c|}
\hline Interval & $\mathrm{F}$ & $Y$ & $f Y$ & $Y^{\prime}$ & $Y^{\prime 2}$ & $\mathrm{fY}^{\prime}$ & $f Y^{\prime 2}$ \\
\hline $90-98$ & 1 & 94 & 94 & +2 & 4 & 2 & 4 \\
\hline $81-89$ & 2 & 85 & 170 & +1 & 1 & 2 & 2 \\
\hline $72-80$ & 13 & 76 & 988 & 0 & 0 & 0 & 0 \\
\hline $63-71$ & 8 & 67 & 536 & -1 & 1 & -8 & 8 \\
\hline $54-62$ & 2 & 58 & 116 & -2 & 4 & -4 & 8 \\
\hline $45-53$ & 1 & 49 & 49 & -3 & 9 & -3 & 9 \\
\hline Jumlah & $\begin{array}{l}\mathrm{N} \\
=27\end{array}$ & $\begin{array}{l}Y \\
=429\end{array}$ & $\begin{array}{l}f Y \\
=1953\end{array}$ & & & $\begin{array}{l}f Y^{\prime} \\
=-11\end{array}$ & $\begin{array}{l}f Y^{\prime 2} \\
=31\end{array}$ \\
\hline
\end{tabular}

Mencari

mean data:

My

$$
\begin{aligned}
\frac{\Sigma f y}{N}= & \\
& =\frac{1953}{27} \\
& =72
\end{aligned}
$$


Idzi’ Layyinati

Mencari Standar deviasi:

$$
\begin{aligned}
\text { SDy } \quad & =i \sqrt{\sum \frac{f y}{N}-\left(\frac{\Sigma f y}{N}\right)^{2}} \\
& =9 \sqrt{\frac{31}{27}-\left(\frac{-11}{27}\right)^{2}} \\
& =9 \sqrt{1,14-(-0,407)^{2}} \\
& =9 \sqrt{0,98} \\
& =9 \times 0,98 \\
& =8,82
\end{aligned}
$$

Mencari nilai tinggi, sedang, dan rendah dengan

$$
\begin{aligned}
& \text { Tinggi } \quad=\text { My }+1 \times \\
& \quad \text { SDy } \\
& =72,3+1 \times 8,82 \\
& =81,12 \\
& =\text { di bulatkan menjadi } 81 \\
& \\
& \text { Jadi, yang termasuk kategori nilai tinggi adalah } 81
\end{aligned}
$$

ke atas

$$
\begin{aligned}
\text { Sedang } & =\mathrm{My}-1 \times \mathrm{SDy} \mathrm{s} / \mathrm{d} \mathrm{My}+1 \times \mathrm{SDy} \\
& =72,33-1 \times 8,82 \mathrm{~s} / \mathrm{d} 72,33+1 \times 8,82 \\
& =63,51 \mathrm{~s} / \mathrm{d} 81,12 \\
& =\text { di bulatkan menjadi } 64 \mathrm{~s} / \mathrm{d} 81 \\
& \text { Jadi, kategori nilai sedang yaitu antara } 64 \mathrm{~s} / \mathrm{d} 81 \\
& =\mathrm{My}-1 \times \mathrm{SDy} \\
& =72,33-1 \times 8,82 \\
& =63,51 \\
& =\text { di bulatkan menjadi } 64 \\
& \text { Karena nilai } 64 \text { sudah termasuk ke dalam kategori }
\end{aligned}
$$

nilai sedang.

Jadi, nilai 64 ke bawah termasuk kategori nilai rendah. 
Tabel. 9

\section{Persentase Hasil Belajar Siswa Kelas III Sesudah Penerapan Media Benda Asli}

\begin{tabular}{|l|ll|l|l|l|}
\hline No. & $\begin{array}{l}\text { Hasil Belajar } \\
\text { Matematika }\end{array}$ & Nilai & Frekuensi & $\begin{array}{l}\text { Persentas } \\
\mathrm{e}\end{array}$ \\
\hline 1 & $\begin{array}{l}\text { Tinggi } \\
2\end{array}$ & Sedang & 61 ke atas & 3 & $11,11 \%$ \\
\hline 3 & Rendah & $\begin{array}{l}64 \text { s } 81 \\
\text { bawah }\end{array}$ & 20 & $74,07 \%$ \\
\hline & \multicolumn{3}{|c|}{ Jumlah } & N $=27$ & $100 \%$ \\
\hline
\end{tabular}

Berdasarkan tabel di atas dapat diketahui bahwa hasil belajar Matematika siswa sesudah digunakan media benda asli yang tergolong tinggi sebanyak 3 orang siswa $(11,11$ $\%)$, tergolong sedang sebanyak 20 orang siswa $(74,07 \%)$, dan yang tergolong rendah sebanyak 4 siswa $(14,82 \%)$.

Dengan demikian hasil belajar Matematika siswa sesudah diterapkan media benda asli pada siswa kelas III di MI Muhammadiyah 06 Tebluru dapat dinterpretasikan bahwa hasil belajar pada post-test mengalami peningkatan skor mean jika dibandingkan dengan pre-test yaitu 57 (pre-test) meningkat menjadi 72 (posttest).

Hipotesis dalam penelitian ini adalah ada atau tidak ada pengaruh penggunaan media benda asli terhadap hasil belajar siswa dalam mata pelajaran Matematika kelas III Madrasah Ibtidaiyah Muhammadiyah 06 Tebluru Kecamatan Solokuro Kabupaten
Lamongan Tahun Pelajaran 2017 - 2018. Dengan menggunakan uji kesamaan dua rata-rata: uji dua pihak, diperoleh rumusan hipotesis sebagai berikut:

Ha: Bahwa terdapat pengaruh hasil belajar yang signifikan terhadap penggunaan media benda asli pada Mata Pelajaran Matematika Kelas III di Madrasah Ibtidaiyah Muhammadiyah 06 Tebluru.

Ho: Bahwa tidak terdapat pengaruh hasil belajar yang signifikan terhadap penggunaan media benda asli pada Mata Pelajaran Matematika kelas III di Madrasah Ibtidaiyah Muhammadiyah 06 Tebluru.

Uji statistik tentang berhasil atau tidak penggunaan media benda asli pada mata pelajaran Matematika kelas III di Madrasah Ibtidaiyah Muhammadiyah 06 Tebluru. 
Idzi’ Layyinati

Peneliti disini menggunakan uji statistik dengan rumus uji tes " $\mathrm{t}$ " (t hitung) untuk mengetahui ada tidaknya pengaruh penggunaan media benda asli pada Mata Pelajaran Matematika di Madrasah Ibtidaiyah Muhammadiyah 06 Tebluru terhadap belajar siswa.

Uji statistik dengan menggunakan rumus uji " $\mathrm{t}$ "

$$
\mathrm{t}_{\mathrm{o}}=\frac{M D}{S E \mathrm{MD}}
$$

Adapun langkah

perhitungannya sebagai berikut:

a. Mencari $\mathrm{D}$

Difference $=$ Perbedaan) antara skor Variabel $\mathrm{X}$ dan skor Variabel Y, maka D = $\mathrm{X}-\mathrm{Y}$

b. Menjumlahkan $\mathrm{D}$, sehingga diperoleh $\sum \mathrm{D}$

c. Mencari Mean dari Difference, dengan rumusan

$$
M D \frac{\sum \mathrm{D}}{N}
$$

d. Mengkuadratkan D sehingga diperoleh $\sum \mathrm{D}^{2}$

e. Mencari Deviasi Standar dari Difference (SDD)

f. Mencari Standar Error dari Mean of Difference, yaitu SEMD dengan menggunakan rumus

g. Mencari $t_{0}$

h. Memberikan interpretasi terhadap $\mathrm{t}_{\mathrm{o}}$ dengan melakukan perbandingan antara $t_{o}$ dengan patokan

a) Jika $t_{0}$ lebih besar atau sama dengan $t_{t}$ maka Hipotesa nihil ditolak ; sebaliknya Hipotesa alternative diterima atau ditujui. Berarti antara kedua variable yang sedang kita selidiki perbedaannya, secara signifikasi memang terdapat pengaruh.

b) Jika $t_{0}$ lebih kecil dari pada $t_{t}$ maka Hipotesa nihil diterima; sebaliknya Hipotesa alternative ditolak. Berarti bahwa perbedaan antara variable I dan variable II itu bukanlah perbedaan yang berarti, tidak terdapat pengaruh.

i. Menarik kesimpulan hasil penelitian

Dalam hubungan ini, dari sejumlah 27 orang siswa Madrasah Ibtidaiyah Muhammadiyah 06 Tebluru yang ditetapkan sebagai sampel penelitian, telah berhasil dihimpun data berupa skor hasil belajar mereka pada pretest (sebelum digunakannya media benda asli) dan skor yang melambangkan hasil belajar mereka pada posttest (sesudah digunakannya media benda asli) pada tabel berikut: 
Pengaruh Penerapan Media Benda Asli Pada Mata Pelajaran Matematika

Tabel. 9

Skor Hasil Belajar Siswa dari 27 Orang Siswa Madrasah Ibtidaiyah Muhammadiyah 06 Tebluru pada Saat Pre-Test dan Post-Test

\begin{tabular}{|c|l|l|l|}
\hline \multirow{2}{*}{ No } & \multicolumn{2}{|c|}{ Nama Siswa } & \multicolumn{2}{|c|}{ Skor Hasil Belajar } \\
\cline { 3 - 4 } & & $\begin{array}{l}\text { Pre-Test } \\
(\mathbf{X})\end{array}$ & $\begin{array}{l}\text { Post-Test } \\
(\mathbf{Y})\end{array}$ \\
\hline 1 & Ain Dwi K. & 52 & 72 \\
\hline 2 & Aisyatul Dayana & 55 & 70 \\
\hline
\end{tabular}

\begin{tabular}{|c|c|c|c|}
\hline 3 & Akbar Aditya R. & 58 & 80 \\
\hline 4 & Amilatus Sholihah & 48 & 63 \\
\hline 5 & Amiluddin. & 58 & 78 \\
\hline 6 & Anastasyahilah & 35 & 45 \\
\hline 7 & Batrisyia Elkasih & 55 & 72 \\
\hline 8 & Batrisyia Wanda & 52 & 62 \\
\hline 9 & Berrin Widiyanata & 48 & 68 \\
\hline 10 & Dannel Faruqi A. & 47 & 68 \\
\hline 11 & Dhamar Althof F. & 57 & 78 \\
\hline 12 & Eka Setiyawati & 52 & 75 \\
\hline 13 & Fikri Haikal & 57 & 75 \\
\hline 14 & Firas Aqil & 63 & 87 \\
\hline 15 & Hafizah Khaira & 70 & 78 \\
\hline 16 & Ir laniyah A. & 60 & 77 \\
\hline 17 & Kayla Putri M. & 55 & 70 \\
\hline 18 & Kelvin Aditya & 63 & 82 \\
\hline 19 & M. Athok A. & 63 & 65 \\
\hline
\end{tabular}


Idzi’ Layyinati

\begin{tabular}{|c|l|c|l|}
\hline 20 & Miftakhul Jannah & 45 & 60 \\
\hline 21 & M. Nawaf Al Mubarok & 52 & 75 \\
\hline 22 & M. Reyhan Ferrari. & 65 & 72 \\
\hline 23 & Ratna Angelina & 55 & 68 \\
\hline 24 & Rizky Andesta & 63 & 70 \\
\hline
\end{tabular}

\begin{tabular}{|c|l|c|l|}
\hline \multirow{2}{*}{ No } & \multicolumn{2}{|c|}{ Nama Siswa } & \multicolumn{2}{|c|}{ Skor Hasil Belajar } \\
\cline { 3 - 4 } & & $\begin{array}{l}\text { Pre-Test } \\
(\mathbf{X})\end{array}$ & $\begin{array}{l}\text { Post-Test } \\
(\mathbf{Y})\end{array}$ \\
\hline 25 & Yosi Afmi A. & 58 & 72 \\
\hline 26 & Zahira Aurotsana & 58 & 80 \\
\hline 27 & Zayed Ar Rahman & 77 & 93 \\
\hline
\end{tabular}


Tabel. 10

Perhitungan untuk Memperoleh $t$ dalam Rangka Menguji Kebenaran / Kepalsuan Hipotesa Tentang Adanya Pengaruh Penerapan Media Benda Asli dalam Pembelajaran Matematika

\begin{tabular}{|c|c|c|c|c|c|}
\hline \multirow{2}{*}{ No } & \multirow{2}{*}{ Nama Siswa } & \multicolumn{2}{|c|}{ Skor Hasil Belajar } & \multirow{2}{*}{$\begin{array}{c}\mathbf{D}= \\
(\mathbf{X}-\mathbf{Y})\end{array}$} & \multirow{2}{*}{$\begin{array}{l}D^{2}= \\
(X-Y)^{2}\end{array}$} \\
\hline & & $\begin{array}{l}\text { Pre-Test } \\
\text { (X) }\end{array}$ & $\begin{array}{l}\text { Post-Test } \\
\text { (Y) }\end{array}$ & & \\
\hline 1 & Ain Dwi K. & 52 & 72 & -20 & 400 \\
\hline 2 & Aisyatul Dayana & 55 & 70 & -15 & 225 \\
\hline 3 & Akbar Aditya R. & 58 & 80 & -22 & 484 \\
\hline 4 & Amilatus Sholihah & 48 & 63 & -15 & 225 \\
\hline 5 & Amiluddin. & 58 & 78 & -20 & 400 \\
\hline 6 & Anastasyahilah & 35 & 45 & -10 & 100 \\
\hline 7 & Batrisyia Elkasih & 55 & 72 & -17 & 289 \\
\hline 8 & Batrisyia Wanda & 52 & 62 & -10 & 100 \\
\hline 9 & Berrin Widiyanata & 48 & 68 & -20 & 400 \\
\hline 10 & Dannel Faruqi A. & 47 & 68 & -21 & 441 \\
\hline 11 & Dhamar Althof F. & 57 & 78 & -21 & 441 \\
\hline 12 & Eka Setiyawati & 52 & 75 & -23 & 529 \\
\hline 13 & Fikri Haikal & 57 & 75 & -18 & 324 \\
\hline 14 & Firas Aqil & 63 & 87 & -24 & 576 \\
\hline 15 & Hafizah Khaira & 70 & 78 & -8 & 64 \\
\hline
\end{tabular}




\begin{tabular}{|c|c|c|c|c|c|}
\hline \multirow{2}{*}{ No } & \multirow{2}{*}{ Nama Siswa } & \multicolumn{2}{|c|}{ Skor Hasil Belajar } & \multirow{2}{*}{$\begin{array}{l}\mathbf{D}= \\
(\mathbf{X}-\mathbf{Y})\end{array}$} & \multirow{2}{*}{$\begin{array}{l}D^{2}= \\
(X-Y)^{2}\end{array}$} \\
\hline & & $\begin{array}{l}\text { Pre-Test } \\
\text { (X) }\end{array}$ & $\begin{array}{l}\text { Post-Test } \\
\text { (Y) }\end{array}$ & & \\
\hline 16 & I'laniyah A. & 60 & 77 & -17 & 289 \\
\hline 17 & Kayla Putri M. & 55 & 70 & -15 & 225 \\
\hline 18 & Kelvin Aditya & 63 & 82 & -19 & 361 \\
\hline 19 & M. Athok A. & 63 & 65 & -2 & 4 \\
\hline 20 & Miftakhul Jannah & 45 & 60 & -15 & 225 \\
\hline 21 & $\begin{array}{l}\text { M. Nawaf } \mathrm{Al} \\
\text { Mubarok }\end{array}$ & 52 & 75 & -23 & 529 \\
\hline 22 & M. Reyhan Ferrari. & 65 & 72 & -7 & 49 \\
\hline 23 & Ratna Angelina & 55 & 68 & -13 & 169 \\
\hline 24 & Rizky Andesta & 63 & 70 & -7 & 49 \\
\hline 25 & Zahira Aurotsana & 58 & 72 & -14 & 196 \\
\hline 26 & Zayed Ar Rahman & 58 & 80 & -22 & 484 \\
\hline 27 & Yosi Afmi A. & 77 & 93 & -16 & 256 \\
\hline & $\mathrm{N}=27$ & & & $\begin{array}{l}\sum \mathrm{D}= \\
-439\end{array}$ & $\begin{array}{l}\sum \mathrm{D}^{L}= \\
7834\end{array}$ \\
\hline
\end{tabular}

Dari table di atas telah berhasiL

diperoleh $\sum \mathrm{D}=-439$ dan $\sum \mathrm{D}^{2}=$ 8009. Dengan diperolehnya $\sum \mathrm{D}=-$ 439 dan $\sum \mathrm{D}^{2}=7834$ tu, maka dapat diketahui besarnya Deviasi Standar Perbedaan skor antara variable $\mathrm{X}$ dan variable $\mathrm{Y}$ (dalam hal ini SDD):

$$
\text { a. } \begin{aligned}
M D & =\frac{\Sigma \mathrm{D}}{N} \\
& =\frac{-439}{27} \\
& =-16,25
\end{aligned}
$$

b. Mencari Deviasi Standar

$$
S D D=\sqrt{\frac{\Sigma \mathrm{D}^{2}}{N}-\left(\frac{\Sigma \mathrm{D}}{N}\right)^{2}}
$$

$$
\begin{gathered}
= \\
\sqrt{\frac{7834}{27}-\left(\frac{-439}{27}\right)^{2}} \\
= \\
\sqrt{290,14-(-16,25)^{2}}
\end{gathered}
$$

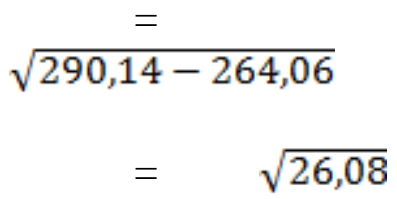

$=\quad 5,10$ 
c. Mencari Standar Error dengan rumus

$$
\begin{aligned}
\text { SEMD } & D=\frac{S D D}{\sqrt{N-1}} \\
= & \frac{5,10}{\sqrt{27-1}} \\
= & \frac{5,10}{\sqrt{26}} \\
= & \frac{5,10}{\sqrt{5,09}} \\
= & 1,001
\end{aligned}
$$

d. Mencari " $t$ " atau $t_{o}$

$$
\begin{aligned}
\mathrm{t}_{\mathrm{o}} & =\frac{M D}{S E_{\mathrm{MD}}} \\
& =\frac{-16,25}{1,001} \\
& =-16,23
\end{aligned}
$$

Langkah berikutnya, diberikan interprestasi terhadap $\mathrm{t}_{0}$ dengan terlebih dahulu memperhitungkan $\mathrm{df}$ atau db nya: $\mathrm{db}=\mathrm{N}-1=27-1=26$. Dengan df sebesar 26 dikonsultasikan pada tabel nilai t, pada taraf signifikansi $5 \%$. Sebagai berikut:

- Pada taraf signifikansi $5 \%: \mathrm{t}_{\mathrm{t}}=$ 2,06

Dengan demikian $t_{o}$ (yaitu sebesar 16,23) adalah jauh lebih besar dari pada $t_{t}$, pada taraf signifikansi $5 \%$. Dengan demikian, maka $\mathrm{H}_{\mathrm{o}}$ yang menyatakan tidak ada pengaruh positif antara media benda asli pada mata pelajaran Matematika terhadap hasil belajar siswa ditolak. Dan $\mathrm{H}_{\mathrm{a}}$ yang menyatakan bahwa terdapat pengaruh positif antara media benda asli pada mata pelajaran Matematika terhadap hasil belajar siswa diterima. Ini berarti bahwa adanya perbedaan skor ataupun hasil belajar siswa antara yang sebelum dan sesudah diterapkan media benda asli pada mata pelajaran Matematika terhadap hasi belajar siswa. Jadi, karena $t_{o}$ lebih besar daripada $t_{t}$ maka hipotesa nihil yang diajukan ditolak, ini berarti bahwa ada pengaruh penerapan media benda asli terhadap hasil belajar siswa.

\section{Penutup}

\section{Kesimpulan}

Hasil uji hipotesis dengan membandingkan besarnya $t$ yang diperoleh dalam perhitungan $\left(t_{0}=\right.$ 16,23) dan besarnya $t$ yang tercantum pada tabel $\left(\mathrm{t}_{\mathrm{t} \text { ts. }} \%\right.$ \% $=$ 2,06) dan $\left.t_{\text {t.ts. } 1 \%}=2,78\right)$ maka dapat diketahui bahwa $t_{0}$ lebih besar $t_{t}$; yaitu 16,23>2,78. Jadi, karena $t_{o}$ lebih besar dari pada $t_{t}$ maka hipotesa nihil yang diajukan ditolak, ini berarti 
bahwa adanya pengaruh penerapan media benda asli terhadap hasil belajar siswa kelas III di Madrasah Ibtidaiyah Muhammadiyah 06 Tebluru Kecamatan Solokuro Kabupaten Lamongan Tahun Pelajaran 2017 -2018 .

\section{Saran}

Berdasarkan pada hasil penelitian yang telah dilakukan disarankan perlunya bimbingan yang lebih menyeluruh kepada siswa serta perlunya persiapan mengenai alat dan fungsinya pada, adanya penggandaan alat-alat sederhana yang dibutuhkan siswa dalam pembelajaran sehingga siswa dapat melakukan percobaan untuk menjawab permasalahan yang dikemukakan pada konsep pembelajaran jika tidak bisa dilakukan pengadaan alat maka disediakan alat dan bahan alternativ untuk percobaan yang dilakukan siswa.

\section{Daftar Pustaka}

Amin, Muhammad Asri. 2013. Menjadi Guru Profesional. Bandung: Penerbit Nuansa Cendekia.

Annur, Saipul. 2014. Metodologi Penelitian Pendidikan Analisis Data Kuantitatif dan Kualitatif. Palembang: Noer Fikri Offset.

Apriani. 2009. Pelaksanaan Pendekatan pendidikan Matematika Realistik Indonesia terhadap Hasil Belajar Materi Bangun Datar di Kelas V Madrasah Ibtidaiyah
Nurul Yaqin Palembang. Palembang: Perpustakaan IAIN Raden Fatah Palembang.

Aqib, Zainal. 2013. Model Model, Media, dan Strategi Pembelajaran Kontekstual (Inovatif). Bandung: Yrama Widya.

Dalyono, M. 2008. Psikologi Pendidikan. Jakarta: Raja Grafindo Persada.

Daryanto. 2013. Media Pembelajaran Peranannya Sangat Penting Dalam Mencapai Tujuan Pembelajaran. Yogyakarta: Gava Media

Departemen Agama RI. 2005. Kurikulum 2004-Standar Kompetensi (Madrasah Ibtidaiyah) Cet. Ke-2. Jakarta: Departemen Pendidikan Nasional

Djamarah, Syaiful Bahri dan Aswan Zain. 2013. Strategi Belajar Mengajar. Jakarta: Rineka Cipta

Hamalik Oemar. 2011. Proses Belajar Mengajar. Jakarta: Bumi Aksara. Hamalik, Oemar. 2013. Kurikulum dan Pembelajaran. Jakarta: PT. Bumi Aksara.

Hamiyah, Nur dan Muhammad Jauhar. 2014. Strategi Belajar Mengajar di Kelas.

Jakarta: Prestasi Pustaka.

Harto, Kasinyo. 2012. Desain Pembelajaran Agama Islam untuk Sekolah dan Madrasah. Jakarta: Rajawali Per

Ibrahim, R dan Nana Syaodih. 2010. Perencanaan Pengajaran. Jakarta: Rineka Cipta. 
Ismail, Fajri. 2014. Evaluasi Pendidikan. Palembang: Tunas Gemilang Press. Khodijah, Nyayu. 2014. Psikologi Pendidikan. Jakarta: PT. Raja Grafindo Persada.

Kunandar. 2013. Penilaian Autentik (Penilaian hasil belajar peserta didik berdasarkan kurikulum 2013). Jakarta: Grafindo Persada

Maryana, Dina. 2010. Upaya Guru Meningkatkan Hasil BelajarMatematika Melalui Model Pembelajaran Group Investigation (Studi kasus di Kelas V MIN Bitis Kecamatan Gelumbang Kabupaten Muara Enim). Palembang: Perpustakaan IAIN Raden Fatah Palembang.

Munadi, Yuhdi. 2013. Media Pembelajaran. Jakarta: REFERENSI.

Muslich, Masnur. 2009. Melaksanakan PTK Penelitian Tindakan Kelas. Jakarta: Bumi Aksara.

Nurahman, Idi. 2010. Upaya Meningkatkan Hasil belajar Murid pada Pelajaran Matematika Melalui Metode Jarimatika di Kelas II MIN Menanti Kecamatan Kelekar Kabupaten Muara Enim. Palembang: Perpustakaan IAIN Raden Fatah Palembang.

Rohani, Ahmad. 1997.

Media Instruksional

Edukatif. Jakarta:

Rineka Cipta.

Rusmaini. 2011.

Ilmu Pendidikan.

Palembang: Grafika

Telindo Press.
Sudijono, Anas. 2010. Pengantar Statistik Pendidikan. Jakarta: Rajawali Press

Sudijono, Anas. 2012. Pengantar Evaluasi Pendidikan. Jakarta: Raja Grafindo Persada.

Sudjana, Nana dan Ahmad Rivai. 2011. Media Pengajaran. Bandung: Sinar Baru Algensindo.

Sugiyono. 2010. Metode Penelitian Pendidikan Pendekatan Kuantitatif, Kualitatif, dan $R \& D$. Bandung: Alfabeta.

Suprijono, Agus. 2009. Cooperative Learning. Yogyakarta: Pustaka Pelajar.

Susanti. 2013. Penerapan Metode Diskusi Untuk Meningkatkan Hasil Belajar Siswa pada Mata Pelajaran Matematika Kelas XII MA. ARRIYADH Palembang. Palembang: Perpustakaan IAIN Raden Fatah Palembang.

Susanto, Ahmad. 2013. Teori Belajar dan Pembelajaran diSekolah Dasar. Jakarta: Kencana.

Syah, Muhibbin. 2012. Psikologi Belajar. Jakarta: PT. Raja Grafindo Persada.

Zaimawati. 2014. Pengaruh Metode Mengajar Guru Terhadap Hasil Belajar Siswa pada mata pelajaran Matematika di SMP Negeri 1 Pemulutan Kecamatan Pemulutan Kabupaten Ogan Ilir. Palembang: Perpustakaan IAIN Raden Fatah Palembang. 
Idzi’ Layyinati

154 Annaba : Jurnal Pendidikan Islam 